\title{
PERANAN MEDIA PENYULUHAN ELEKTRONIK TERHADAP TINGKAT ADOPSI INOVASI PETANI PADI SAWAH
}

\section{The Role of Electronic Counseling Media On The Adoption Level of Rice Farmer Inovation}

\author{
Arief Sirajuddin, Hermaya Rukka, Ismai Tandi, dan Muzakkir \\ Politeknik Pembangunan Pertanian Gowa \\ e-mail: ariefsirajuddin21@gmail.com
}

Received: 6 Maret 2021; Accepted: 8 Mei 2021; Published: 25 Juni 2021

\begin{abstract}
ABSTRAK
Penggunaan media adalah untuk memperjelas informasi yang disampaikan sehingga dapat merangsang pikiran, perasaan perhatian dan kemampuan sasaran. Media berperan penting dalam memberikan pengalaman yang kongkrit dan sesuai dengan tujuan belajar. misalnya tingkat pendidikan formal petani sangat bervariasi, keterbatasan sarana dan waktu belajar petani. Metode yang digunakan adalah metode survei yaitu meneliti status kelompok manusia, obyek, kondisi, system pemikiran atau peristiwa pada masa sekarang. Penelitian ini bertujuan untuk membuat deskripsi, gambaran atau lukisan secara sistematis, faktual dan akurat mengenai fakta-fakta, sifat-sifat serta hubungan antar fenomena yang diselidiki. Populasi penelitian ini adalah anggota Gapoktan Salewatang berjumlah 380 orang di Desa Kalukuang Kecamatan Galesong Kabupaten Takalar. Metode pengambilan sampel dilakukan secara acak dengan responden yang terdiri dari 2 kelompok yaitu kelompok Berantas dan kelompok Ingin Maju, masing-masing kelompok 25 orang sehingga total responden 50 orang. Hasil Penelitian menunjukkan bahwa peranan media elektronik terhadap tingkat adopsi inovasi petani padi sawah sangat berperan dalam media Pemutaran film terdapat $50 \%$ responden pada kategori tinggi, media internet (media sosial) $50 \%$ kategori sedang, media televisi $54 \%$ kategori tinggi dan media power point $56 \%$ berada pada kategori sedang. Media elektronik yang paling efektif digunakan dalam kegiatan penyuluhan adalah semua media elektronik sangat merespons tingkat adopsi inovasi, namun tingkat keefektifan tergantung dari tujuan penyuluhan yang akan dicapai dimana rata-rata tingkat keefektifan 32,5\% tidak efektif, $44 \%$ cukup efektif dan 23,5\% efektif. Hubungan karakteristik petani terhadap tingkat adopsi inovasi petani padi sawah dengan menggunakan media Elektronik adalah pemutaran film dengan nilai korelasi $0,191 *$, media internet $0,183^{*}$, media televisi 0,062 tidak berpengaruh nyata dan power point nilai korelasi 0,058 juga tidak berkorelasi nyata terhadap tingkat adopsi inovasi dalam penerapan jajar Legowo.
\end{abstract}

Kata kunci: Kelompok tani, penyuluhan pertanian, media penyuluhan, adopsi inovasi

\section{PENDAHULUAN}

Beras merupakan produk utama yang dihasilkan oleh tanaman padi, dimana beras sebagai bahan utama penduduk Indonesia dari 90 persen jumlah penduduk yang ada. Kebutuhan beras tiap tahunnya akan terus bertambah seiring dengan pertambahan jumlah penduduk. Kabupaten Takalar memiliki luas wilayah $566,51 \mathrm{~km}$ persegi, dan salah satu komoditi unggulan sektor pertanian adalah padi, dari 13,183 hektar yang biasanya ditanami 2 kali sehingga mampu memberikan kontribusi besar bagi ketahanan pangan di sulawesi Selatan., luas lahan persawahannya, 70 persen merupakan lahan sawah berpengairan dan selebihnya merupakan lahan sawah tadah hujan. Untuk menciptakan perubahan perilaku masyarakat petani, penyuluh pertanian diharapkan mampu mengarahkan wawasan berfikir dan menumbuhkan karakter sebagai bangsa yang sedang melakukan 
pembangunan (Sastraadmadja, dkk. 2000).

Materi penyuluhan pertanian harus sesuai dengan kebutuhan sasaran (petani) dengan demikian maka petani akan tertarik perhatiannya dan terangsang untuk mempraktekannya. Materi yang menarik perhatian para petani tentunya adalah segala sesuatu yang berkaitan dengan usaha perbaikan produksi, perbaikan tingkat pendapatan dan perbaikan tingkat kehidupannya (Kartasapoetra,2000).

Penyuluhan Pertanian adalah suatu upaya untuk mengubah perilaku petani dan keluarganya, agar mereka mempunyai pengetahuan serta mampu memecahkan masalahnya sendiri dalam usaha atau kegiatan-kegiatan dalam meningkatkan potensi usahataninya. Penjelasan di atas dapat memperlihatkan pentingnya perhatian khusus mengenai masalah-masalah petani terutama yang berada di wilayah perdesaan mengenai sikap petani terhadap materi dan media yang disampaikan oleh petugas-petugas penyuluhan. Materi dan media penyuluhan tersebut seyogianya harus sesuai dengan kebutuhan petani, sosial masyarakat dan karakteristik petani itu sendiri.

Salah satu upaya untuk meningkatkan produksi padi adalah melalui penerapan sistim tanam jajar legowo. Jajar legowo adalah pengosongan satu baris tanaman setiap dua atau lebih baris dan merapatkan dalam barisan tanaman, sehingga dikenal dengan jarwo $2: 1$ atau $4: 1$. Dengan sistim ini populasi tanaman padi meningkat, dapat mengurangi serangan tikus, keong mas, dan keracunan besi. Keuntungan sistim tanam jajar legowo adalah semua rumpun tanaman berada pada bagian pinggir yang biasanya memberi hasil lebih tinggi (efek tanaman pinggir), penggunaan pupuk lebih berdaya guna, pengendalian hama, penyakit dan gulma lebih mudah dan efisien (BPTP, 2013). Berbagai media penyuluhan telah dibuat menyangkut teknologi sistim tanam jajar legowo, sehingga teknologi ini dapat diadopsi oleh petani atau pengguna. Jenis media yang dimaksud seperti leaflet, brosur, liptan, poster, seri foto, penyiaran radio, televisi, website, youtube, power poin, pertemuan kelompok tani, pelatihan, bahkan demplot jajar legowo, dll.
Dengan demikian media berperan penting dalam memberikan pengalaman kongkrit dan sesuai dengan tujuan belajar. Selain dari pada itu media diharapkan dapat lebih mengkongkritkan apa yang dijelaskan komunikator kepada komunikan (sasaran), sehingga sasaran lebih mudah dan lebih cepat menangkap materi, apa yang dilihat sasaran akan terkesan lebih lama dibandingkan dengan didengar dan media mampu memotivasi dan mampu memusatkan perhatian.

Penyuluh Pertanian biasanya dalam melakukan kegiatan penyuluhan tanpa menggunakan media ataupun hanya dengan media tercetak, namun pada Era sekarang di zaman digital petani lebih menyenangi penyampaian materi penyuluhan dengan menggunakan media elektronik. Dengan melihat potensi Kabupaten Takalar diatas maka penulis ingin menjawab beberapa permasalahan yang dihadapi seperti bagaimana peranan media elektronik terhadap tingkat adopsi inovasi petani padi sawah dan Media eletronik yang manakah yang paling efektif digunakan dalam kegiatan penyuluhan padi sawah.

\section{METODE PENELITIAN}

Penelitian ini merupakan penelitian deskriptif dengan metode survei yaitu suatu metode dalam meneliti status kelompok manusia, obyek, kondisi, system pemikiran atau peristiwa pada masa sekarang. Penelitian ini dilaksanakan di Kabupaten Takalar, Kecamatan Galesong, Desa

Untuk mengetahui peranan media elektronik terhadap tingkat adopsi inovasi petani padi sawah dan untuk mengetahui media elektronik yang paling efektif digunakan dalam kegiatan penyuluhan yaitu dengan menggunakan skoring: $3=$ (Tinggi), $2=($ sedang $), 1=($ Rendah $)$.

Teknik analisis data yang digunakan adalah hubungan karakteristik petani terhdap tingkat adopsi inovasi petani padi sawah dengan menggunakan media elektronik yaitu dengan menggunakan rumus Korelasi Rank Spearmen (rs) (Sidney Siegel, 1994) yaitu:

$$
\mathrm{rs}=1-\frac{\mathrm{d}\left(\sum \mathrm{d}\right) 2}{\mathrm{n}(\mathrm{n} 2-1)}
$$


DOI: 10.52625/j-agr-sosekpenyuluhan.v17i1.183

Keterangan:

rs : Koefisien korelasi spearman

d : Beda urutan dalam Pasangan data

$\mathrm{n}$ : Jumlah sampel (Banyaknya pasangan data)

Untuk memudahkan perhitungan digunakan SPSS

(Statistical Produk and Servise Solutions) .

\section{HASIL DAN PEMBAHASAN}

\section{Media Elektronik}

Pelaksanaan usahatani baik secara langsung maupun tidak langsung akan dipengaruhi oleh berbagai faktor luar (eksternal) baik alam , fisik, lingkungan sosial, termasuk berbagai kebijakan dan program-program dari pemerintah.
Faktor eksternal ini sedikit banyak berpengaruh terhadap diri individu petani dalam pengelolaan usahataninya. Penelitian ini menganalisis beberapa karakteristik Media Elektronik melalui empat variabel, yaitu : (1) Pemutaran film (2) Media internet, (3) Media televisi dan (4) Power Point Secara umum media penyuluhan dikelompokkan menjadi empat bagian yaitu media cetak, media audio, media audio visual, dan media benda tiruan dan sesungguhnya. Didesa Kalukuang Kecamatan Galesong jenis media yang diteliti adalah khusus ke media Elektronik yang berkaitan dengan teknologi jajar legowo. Untuk melihat jenis media elektronik yang disenangi oleh sasaran dalam penerimaan materi dapat dilihat pada tabel berikut :

Tabel 1. Sebaran penilaian responden berdasarkan penyampaian materi dengan media elektronik

\begin{tabular}{ccccc}
\hline No & Media Elektronik & Kategori & $\begin{array}{c}\text { Jumlah } \\
(\text { Orang })\end{array}$ & $\begin{array}{c}\text { Persentasi } \\
(\%)\end{array}$ \\
\hline 1. & Pemutaran Film & Rendah & 10 & 20 \\
& & Sedang & 15 & 30 \\
& \multirow{2}{*}{ 2. } & Tinggi & 25 & 50 \\
& & Redia Internet & 10 & 20 \\
& & Sedang & 25 & 50 \\
3. & Media Televisi & Tinggi & 15 & 30 \\
& & Rendah & 11 & 22 \\
& & Sedang & 12 & 24 \\
4. & Power Point & Tinggi & 9 & 54 \\
& & Rendah & 28 & 18 \\
& & Sedang & 13 & 56 \\
\hline
\end{tabular}

\section{Tingkat Keefektifan Media Elektronik}

Penggunaan media penyuluhan adalah suatu hal yang penting dilakukan seorang penyuluh untuk memudahkan sasaran dalam menerima materi yang disampaikan, akan tetapi pada kenyataannya tidak semua media dapat sepenuhnya efektif digunakan untuk menyampaikan materi kepada sasaran. Untuk itu, diharapkan sebelum menggunakan atau membuat suatu media, penyuluh perlu memperhatikan keefektifan media tersebut dalam proses pembelajaran, agar pembelajaran yang akan dilakukan bisa berjalan dengan maksimal.

Tabel 2 terlihat bahwa tingkat keefektifan media elektronik dalam kegiatan penyuluhan menurut responden adalah rata- rata petani responden menilai bahwa penggunaan media elektronik sangat memberikan respons yang cukup dalam penyampaian materi karena media yang ditampilkan sangat menarik dibandingkan dengan media tercetak dengan angka rata-rata cukup efektif (44\%) dan efektif ( $23,5 \%)$.

Diterbitkan Oleh, 
DOI: 10.52625/j-agr-sosekpenyuluhan.v17i1.183

Tabel 2. Sebaran tingkat keefektifan media elektronik dalam kegiatan penyuluhan

\begin{tabular}{|c|c|c|c|c|c|c|c|c|}
\hline \multirow[b]{2}{*}{ No } & \multirow{2}{*}{$\begin{array}{c}\text { Media } \\
\text { Elektronik }\end{array}$} & \multicolumn{7}{|c|}{ Tingkat Keefektifan } \\
\hline & & $\begin{array}{l}\text { Tidak } \\
\text { efektif }\end{array}$ & $\%$ & $\begin{array}{l}\text { Cukup } \\
\text { Efektif }\end{array}$ & $\%$ & Efektif & $\%$ & $\begin{array}{c}\text { Jumlah Responden } \\
\text { (Orang) }\end{array}$ \\
\hline 1. & Film & 13 & 26 & 22 & 44 & 15 & 30 & 50 \\
\hline 2. & Media Internet & 17 & 34 & 21 & 42 & 12 & 24 & 50 \\
\hline 3. & Media Televisi & 23 & 46 & 20 & 40 & 7 & 14 & 50 \\
\hline 4. & Power Point & 12 & 24 & 25 & 50 & 13 & 26 & 50 \\
\hline
\end{tabular}

Hubungan Karakteristik Petani (Umur, Pendidikan Formal, Pengalaman Berusahatani, Luas Lahan Garapan, dan Kekosmopolitan) dengan Tingkat Adopsi Inovasi dalam Penerapan Jajar Legowo

Tabel 3 menunjukkan bahwa umur tidak berhubungan nyata denganTingkat Adopsi Inovasi dalam penerapan Jajar Legowo, dimana nilai probabilitas lebih besar dari 0,05. Hal ini disebabkan bahwa umur tidak berhubungan dengan tingkat adopsi inovasi dalam penerapan jajar legowo, walaupun umur petani masih muda tetapi mempunyai pandangan yang positif terhadap penerapan jajar legowo, demikian juga sebaliknya walaupun petani berumur sudah tua (di atas 50 tahun) tetapi pandangannya terhadap jajar legowo negatif dan petani hanya mau menerapkan apabila produksi tinggi.
Hasil uji pada Tabel 3 terdapat hubungan yang nyata dimana nilai probabilitas 0,016 lebih kecil dari 0,05 ini berarti tolak $\mathrm{H}_{0}$ artinya pendidikan petani berpengaruh terhadap tingkat adopsi Inovasi dalam penerapan jajar legowo. Hal ini juga didukung dengan hasil analisis bahwa sebagian besar petani responden berpendidikan tidak tamat SD sampai SD.

Pendidikan berpengaruh terhadap tingkat pengetahuan dan penguasaan teknologi suatu masyarakat. Masyarakat petani yang tradisional sering dicirikan dengan tingkat pendidikan dan pengetahuan yang rendah. Rendahnya tingkat pendidikan merupakan salah satu faktor penghambat pengembangan sektor pertanian di pedesaan karena pendidikan yang rendah akan mempengaruhi kemampuan petani dalam menerapkan inovasi baru.

Tabel 3. Hubungan karakteristik petani dengan tingkat adopsi inovasi dalam penerapan Jajar Legowo.

\begin{tabular}{clcc}
\hline \multirow{2}{*}{ No } & \multicolumn{1}{c}{ Karakteristik Petani } & \multicolumn{2}{c}{$\begin{array}{c}\text { Tingkat Adopsi Inovasi dalam penerapan } \\
\text { Jajar Legowo }\end{array}$} \\
\cline { 3 - 4 } & & 0,036 & Nilai Probabilitas \\
\hline 1. & Umur & $0,016^{* *}$ & 0.006 \\
2. & Pendidikan Formal & $0,225^{*}$ & 0,014 \\
3. & Pengalaman Berusahatani & 0,128 & 0,191 \\
4. & Luas Lahan Garapan & $0,228 *$ & 0,018 \\
5. & Kekosmopolitan &
\end{tabular}

Keterangan :*) signifikan pada taraf 0,05

**) signifikan pada taraf 0,01

Hasil uji statistik secara parsial diperoleh nilai korelasi 0,225 dengan nilai probabilitas 0,014 yang berarti lebih kecil dari 0,05 , sehingga dapat disimpulkan pengalaman berusahatani berpengaruh terhadap Tingkat Adopsi Inovasi dalam penerapan jajar legowo, hal ini dapat memberikan gambaran para petani telah memiliki pengalaman dalam berusahatani padi, Dari Tabel 14 dapat diartikan makin tinggi pengalaman petani dalam berusahatani maka akan tinggi pula dalam pemahaman dan penerapan sistem tanam jajar Legowo.

Hasil uji analisis pada Tabel 3. menunjukkan bahwa kekosmopolitan berhubungan

Diterbitkan Oleh,

Unit Penelitian dan Pengabdian Masyarakat, Politeknik Pembangunan Pertanian Gowa

http://ejournal.polbangtan-gowa.ac.id 
nyata positif dengan Tingkat Adopsi Inovasi dalam penerapan jajar Legowo. Hal ini berarti bahwa makin tinggi kekosmopolitan petani maka cenderung petani makin mudah dalam menerima suatu inovasi

\section{Hubungan Penggunaan Media Elektronik (Pemutaran Film, Media Internet, Media Televisi, dan Power Point) Dengan Tingkat Adopsi Inovasi dalam penerapan Jajar Legowo}

Variabel-variabel Media Elektronik yang berhubungan dengan tingkat Adopsi Inovasi dalam penerapan Jajar Legowo dapat dilihat pada tabel 4. Film yang dimaksudkan di sini adalah film sebagai alat audio visual untuk penyuluhan. Banyak halhal yang dapat dijelaskan melalui film, antara lain tentang proses yang terjadi dari segala sesuatu dalam suatu bidang pertanian misalnyai, kejadiankejadian dalam alam, dan mengajarkan suatu ketrampilan.

Pemutaran film sebagai suatu faktor penunjang kemajuan usahatani berhubungan nyata positif pada taraf kepercayaan 0,05 dengan tingkat adopsi petani dalam penerapan sistem tanam jajar legowo. Makin sering petani menonton film tentang sistem tanam jajar legowo maka petani akan lebih memahami .

Tabel 4. Hubungan penggunaan media elektronik dengan tingkat adopsi inovasi dalam penerapan Jajar Legowo

\begin{tabular}{llcc}
\hline \multirow{2}{*}{ No } & \multirow{2}{*}{ Media Elektronik } & \multicolumn{2}{c}{$\begin{array}{c}\text { Tingkat Adopsi Inovasi dalam penerapan } \\
\text { Jajar Legowo }\end{array}$} \\
\cline { 3 - 4 } & & Nilai Korelasi & Nilai Probabilitas \\
\hline 1. & Pemutaran Film & $0,191 *$ & 0,034 \\
2. & Media Internet & $0,183^{*}$ & 0,045 \\
3. & Media Televisi & 0,062 & 0,490 \\
4. & Power Point & 0,058 & 0,325 \\
\hline
\end{tabular}

Keterangan : *) signifikan pada taraf 0,05

**) signifikan pada taraf 0,01

Perkembangan media sosial membuat kinerja menjadi lebih cepat, tepat, akurat sehingga dapat meningkatkan produktivitas yang dihasilkan. Adapun media sosial yang sering digunakan petani pada saat ini adalah Facebook, Twitter, Instagram, whatsapp dan media sosial yang lainnya. Dengan menggunakan media sosial petani dapat dengan mudah berkomunikasi jarak dekat maupun jarak jauh tanpa harus bertatap muka atau bertemu. Media sosial bagi para petani merupakan hal yang penting tidak hanya sebagai tempat memperoleh informasi yang menarik tetapi juga sudah menjadi lifestyle atau gaya hidup. Pemanfaatan media sosial sebagai media belajar dapat dikatakan bahwa proses belajar sosial berfokus pada bagaimana seorang individu belajar dengan menjadikan orang lain sebagai subjek belajarnya.

Media Internet dalam hal ini melalui media sosial memberikan hubungan yang positif terhadap penerapan sistem tanam jajar Legowo dengan korelasi $0,183 *$ pada taraf kepercayaan 0,05 . Hal ini berarti makin sering petani responden berinteraksi melalui media sosial maka ada kecendrungan pemahaman petani terhadap sistem tanam jajar legowo akan lebih meningkat.

Televisi adalah sebuah media komunikasi massa yang potensial, tidak saja untuk menyampaikan informasi tetapi juga membentuk perilaku seseorang baik ke arah positif maupun negatif, disengaja atau tidak. Semakin lama TV dirasakan sebagai bagian dari kehidupan manusia dewasa ini, bahkan pada kelompok masyarakat tertentu TV mutlak harus ada dan sulit membayangkan hidup tanpa TV. Ritme dan kegiatan hidup banyak diatur oleh TV, suka atau tidak, sadar ataupun tidak .Luasnya dampak siaran televisi terhadap kehidupan masyarakat, menjadikan TV sebagai media yang efektif dan efisien untuk penyampaian Informasi dan dapat diterima melalui TV kapan saja selama 24 jam. Dampak positif siaran TV tersebut, antara lain masyarakat dapat dengan mudah dan cepat 
memperoleh informasi dari berbagai belahan dunia; dapat menunjang pengembangan ilmu pengetahuan (pendidikan); dan sebagai media hiburan.

Menonton televisi berbeda dengan budaya baca-tulis. kemampuan manusia dalam penerimaan pesan menyebutkan bahwa apabila sebuah pesan diterima hanya dengan perangkat audio atau indera pendengaran semata, maka kemampuan daya tangkapnya adalah $15 \%$. Sedangkan jika dengan audio-visual maka kemampuan daya tangkapnya sebesar 55\%, dan akan meningkat hingga 95\% jika selain audiovisual juga melibatkan emosional, naman berdasarkan tabel 14 menunjukkan bahwa media televisi tidak berhubungan secara positif terhadap tingkat adopsi Inovasi dalam penerapan jajar legowo ini disebabkan karena rata-rata responden menonton televisi dalam bentuk hiburan dan siaran televisi jarang menayangkan tentang informasi pertanian

Media Power Point adalah alat bantu presentasi, biasanya digunakan untuk menjelaskan suatu hal yang dirangkum dan dikemas dalam slide Power Point. Sehingga audiance dapat lebih mudah memahami penjelasan kita melalui visualisasi yang terangkum di dalam slide. Dengan Media Power Point diharapakan semua materi yang disampiakan penyuluh bisa diterima oleh petani. Media Powerpoint memiliki keunggulan/ kelebihan Power Point yaitu salah satu fitur menyediakan kemampuan untuk membuat presentasi yang meliputi musik yang memainkan seluruh presentasi atau efek suara untuk slide tertentu. Berdasarkan Tabel 4 terlihat bahwa penyampain materi melalui media power point tidak berhubungan secara nyata dengan penerapan sistem jajar legowo

\section{KESIMPULAN DAN SARAN}

\section{Kesimpulan}

1. Peranan media elektronik terhadap tingkat adopsi inovasi petani padi sawah sangat berperan pada Pemutaran film terdapat $50 \%$ responden kategori tinggi, media internet (media sosial) $50 \%$ kategori sedang, media televisi $54 \%$ kategori tinggi dan media power point $56 \%$ kategori sedang.

2. Media elektronik paling efektif digunakan dalam kegiatan penyuluhan menurut responden adalah semua media elektronik sangat merespons tingkat adopsi inovasi, namun tingkat keefektifan tergantung dari tujuan penyuluhan yang akan dicapai dimana rata-rata tingkat keefektifan 32,5\% tidak efektif, $44 \%$ cukup efektif dan $23,5 \%$ Efektif.

3. Hubungan karakteristik petani terhadap tingkat adopsi inovasi petani padi sawah dengan menggunakan media Elektronik adalah pemutaran film dengan nilai korelasi 0,191 *, Media Internet $0,183^{*}$, media televisi 0,062 tidak berpengaruh nyata dan power point nilai korelasi 0,058 artinya tidak juga berkorelasi nyata dengan tingkat adopsi inovasi dalam penerapan jajar Legowo.

\section{Saran}

Berdasarkan pembahasan dan kesimpulan, maka ditarik beberapa saran antara lain:

1. Perlunya menggabungkan beberapa media penyuluhan dalam adopsi teknologi jajar legowo pada kegiatan penyuluhan karena media penyuluhan yang digunakan penyuluh pada saat penyuluhan memiliki kelemahan dan keunggulan.

2. Perlunya pelatihan kompetensi kepada para penyuluh agar dapat membuat dan menggunakan media penyuluhan elektronik yang lebih menarik dan diminati oleh petani.

\section{DAFTAR PUSTAKA}

Arikunto S, 1997. Prosedur Penelitian Suatu Pendekatan Praktek. Rineka Cipta, Jakarta.

, 2006. Undang-undang Nomor 16 Tahun 2006 tentang Sistem Penyuluhan Pertanian, Perikanan dan Kehutanan. Jakarta

,2013. Peraturan Menteri Pertanian Nomor : 82/permentan /OT.140/8/2013 tentang Pedoman Pembinaan Kelompotani dan Gabungan Kelompoktani Jakarta

Hafsah, M.J, 2009. Penyuluhan pertanian di era otonomi daerah. Pustaka Sinar Harapan. Jakarta.

E.Oosmukhamad Anwas, 2010. Pemanfaatan Media Dalam Pengembangan Kompetensi. IPB (Disertasi).

Diterbitkan Oleh,

Unit Penelitian dan Pengabdian Masyarakat, Politeknik Pembangunan Pertanian Gowa

http://ejournal.polbangtan-gowa.ac.id 
DOI: 10.52625/j-agr-sosekpenyuluhan.v17i1.183

Mardikanto T, 2003. Redifinisi dan revitalisasi penyuluhan pembangunan. IPB Press. Bogor.

Moehar D, dkk. 2006. PRA (Participatory Rural Appraisal) Pendekatan Efektif Mendukung Penerapan Penyuluhan Partisipatif Dalam Upaya Percepatan Pembangunan Pertanian. Bumi Aksara. Jakarta.

Nazir M, Ph .D, 2005. Metode Penelitian. Ghalia Indonesia, Bogor.

Nurkinan,Drs,M.M , 2017. Dampak Media On Line Terhadap Perkembangan Media Konvensional, Jurnal Politikom Indonesia, Vol 2 No. 2 November.
Pambudy, R. 2003. Penyuluhan Dalam Sistem dan Usaha Agribisnis : Strategi Pengembangan Modal Manusia Indonesia. IPB Press.

Siegel, Sidney.1994. Statistik Non Parametrik.PT. Raja Grafindo Persada.

Sunyoto Usman, Dr. 2004. Pembangunan dan Pemberdayaan Masyarakat. Pustaka Pelajar. Yogyakarta.

Umar, H. 2007. Metode penelitian untuk skripsi dan tesis bisnis. Raja Grafindo Persada. Jakarta.

Van den Ban, Hawkins. 1999. Penyuluhan pertanian. Kanisius. Yogyakarta. 